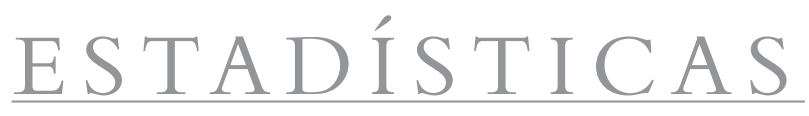

Cuadernos de Música Iberoamericana, VOLUMEN 30, 2017

\title{
Estadísticas anuales
}

Artículos recibidos: 19

Aceptados: 9

Rechazados: 8

Publicados: 7

En proceso: 4 